University of Nebraska - Lincoln

DigitalCommons@University of Nebraska - Lincoln

Quantitative Mass Production of Hydrotaea aenescens (Diptera: Muscidae)

Jerome Hogsette

USDA-ARS, Jerry.Hogsette@ars.usda.gov

Frank Washington

USDA-ARS

Follow this and additional works at: https://digitalcommons.unl.edu/usdaarsfacpub

Part of the Agricultural Science Commons

Hogsette, Jerome and Washington, Frank, "Quantitative Mass Production of Hydrotaea aenescens (Diptera: Muscidae)" (1995). Publications from USDA-ARS / UNL Faculty. 1008.

https://digitalcommons.unl.edu/usdaarsfacpub/1008

This Article is brought to you for free and open access by the U.S. Department of Agriculture: Agricultural Research Service, Lincoln, Nebraska at DigitalCommons@University of Nebraska - Lincoln. It has been accepted for inclusion in Publications from USDA-ARS / UNL Faculty by an authorized administrator of DigitalCommons@University of Nebraska - Lincoln. 


\title{
Quantitative Mass Production of Hydrotaea aenescens (Diptera: Muscidae)
}

\author{
JEROME A. HOGSETTE AND FRANK WASHINGTON
}

Medical and Veterinary Entomology Research Laboratory, USDA-ARS, P.O. Box 14565, Gainesville, FL 32604

\begin{abstract}
J. Econ. Entomol. 88(5): 1238-1242 (1995)
ABSTRACT A covered oviposition device was developed that allows collection of large numbers of Hydrotaea aenescens (Wiedemann) (formerly Ophyra aenescens) eggs. Eggs can be measured and known numbers added to larval rearing medium so this beneficial fly can be reared quantitatively for the first time. With the use of quantitative rearing techniques and a new diet consisting of 5 parts Gainesville house fly diet and 1 part meat and bone meal, $H$. aenescens can be mass-reared easily for biological control studies.
\end{abstract}

KEY WORDS Hydrotaea aenescens, Ophyra aenescens, rearing, facultative predator, larval diet, oviposition

Hydrotaea aenescens (WIEDEMANN) (formerly Ophyra aenescens), the black dump fly, is a facultative larval predator that has been shown to be beneficial for control of filth fies, especially the house fly, Musca domestica L., on poultry and swine farms (Nolan and Kissam 1985, Ribbeck et al. 1987, Turner and Carter 1990, Betke et al. 1991, Turner et al. 1992). This shiny black muscoid fly was introduced, probably through commerce, from the Americas to Europe in the 1960s (Sick 1971, Adams 1984). Since then, its potential as a biological control agent has been evaluated on both sides of the Atlantic (Hogsette 1979, Müller 1982, Geden et al. 1988, Farkas and Jantnyik 1990, Farkas and Papp 1990).

Reports of $H$. aenescens colonization (Roddy 1955, Johnson and Venard 1957, Hogsette 1979, Müller 1982) and mass-rearing techniques (Turner and Carter 1990) can be found in the literature, but none of these authors used the same larval rearing medium. One medium is agar based (Roddy 1955), another is clay based (Müller 1982), and others are grain based (Johnson and Venard 1957, Hogsette 1979, Turner and Carter 1990); some required advanced preparation of materials (Roddy 1955, Hogsette 1979).

Johnson and Venard (1957) added an estimated $300-400$ eggs to a measured amount of prepared larval medium to replenish their small laboratory colony. However, $H$. aenescens in most other colonies was not produced with quantitative methods because suitable egg collection techniques for this fly had not been developed. Turner and Carter (1990) allowed $H$. aenescens females to oviposit for a specified period on trays of prepared medium and found that an average of 1,700 adults emerged per tray. Although this is quite acceptable for mass rearing in the field, a quantitative method is need- ed for laboratory studies where large numbers of uniform-age, uniform-size flies are required.

One objective of this study was to develop a simple method for collecting large numbers of $H$. aenescens eggs and thus develop a quantitative method of production. A 2nd objective was to develop a basic larval medium for $H$. aenescens based on the Gainesville house fly diet, which is currently used to produce house flies, and stable flies, Stomoxys calcitrans (L.), at the USDA Medical and Veterinary Entomology Research Laboratory (Hogsette 1992).

\section{Materials and Methods}

The $H$. aenescens colony was established in 1990 from adults collected on a caged layer farm near Dover, Hillsborough County, Florida, in an outbuilding used for long-term storage of spoiled feed and manure spillage.

Basic rearing techniques were similar to those used by Hogsette (1992), unless otherwise stated. All diets with developing larvae were held in the growth chamber at $26.7^{\circ} \mathrm{C}$ and $60 \% \mathrm{RH}$. At the proper time, pupae were separated from diets by Hotation and air dried. Adults were maintained in colony cages ( $46 \mathrm{~cm}$ long by $38 \mathrm{~cm}$ wide by $38 \mathrm{~cm}$ high) and provided with dry food (powdered nilk, granulated sugar, and powdered egg yolk; 6:6:1) (Hogsette and Koehler 1992) and water ad libitum. Fish meal $(2-3 \mathrm{ml})$ was sprinkled over the surface of the dry food as a protein supplement (Hogsette 1979).

Egg Collection. The colony was propagated initially by allowing $H$. aenescens females (5-10 d old) to oviposit in small containers of conditioned medium (medium that had already been used for rearing house fly larvae). Subsequently we tested 

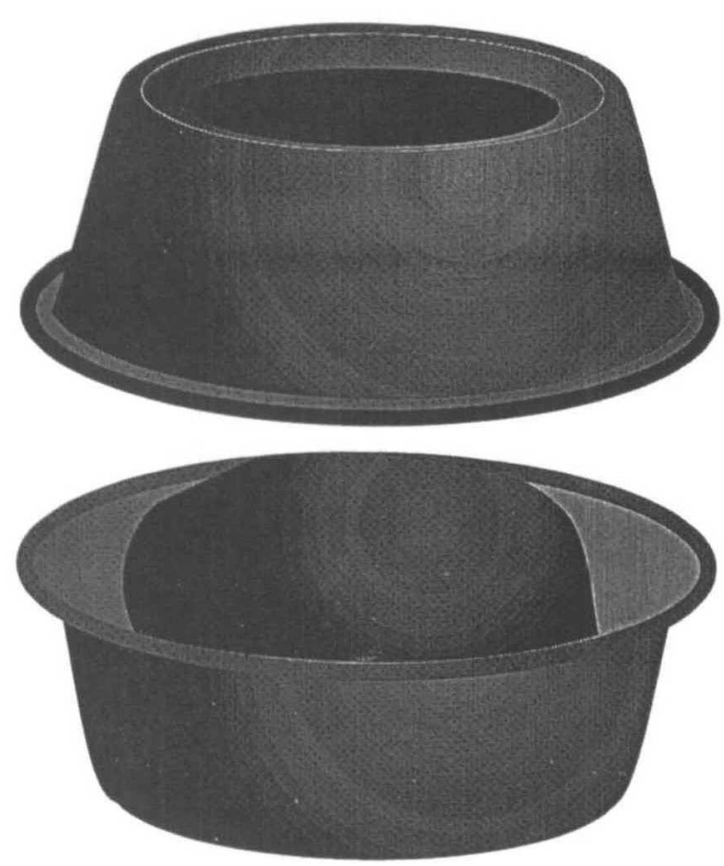

Fix. 1. Covered oviposition device, showing orientation of squat cups and cloth-covered ball of conditioned medium.

the egg collection device we use in our house fly colony (Morgan 1986). To assemble the device, a small ( $6 \mathrm{~cm}$ dianeter) ball of conditioned medium was wrapped in black cloth, moistened with water, and placed in a disposable plastic cup $(6 \mathrm{~cm}$ high by $9 \mathrm{~cm}$ wide). When placed in a cage with 5 - to 7 -d-old house fly adults, females enter the cup and oviposit on the lower portion of the cloth-covered medium.

A covered oviposition device was made by placing the same size cloth-wrapped ball of conditioned medium in a squat cup $(4 \mathrm{~cm}$ high by 11.5 cm wide, Sweetheart Plastics, Wilmington, MA). Water $(4-5 \mathrm{ml})$ was added to saturate the cloth fully and moisten the medium lightly. A 2nd squat cup with a 6 -cm-diameter hole cut in the bottom was inverted and placed on the squat cup containing the ball of medium so that the rims of the cups were contiguous (Fig. 1). The outside surfaces of both cups had been spray painted flat black. $H$. acnescens adults in colony cages were exposed to both devices. After $24 \mathrm{~h}$, devices were removed from the cages and examined for the presence of eggs. Eggs were washed from the black cloth and measured volumetrically.

Diet Selection. Components selected for the $H$. acnescens lanial diet were the Gainesville house fly diet and a protein source. Although Hogsette (1979) used fish meal, we decided to use meat and bone meal because its protein content is similar to that of fish meal (Morrison 1961), it is more readily
Table 1. Composition of test diets used to rear $H$. aenescens in the laboratory

\begin{tabular}{lcccc}
\hline \hline \multirow{2}{*}{ Diet $\begin{array}{c}\text { GHFD : } \\
\text { MBM }^{2} \text { ratio }\end{array}$} & \multicolumn{3}{c}{ Components, ml } \\
\cline { 3 - 5 } & $1: 1$ & GHFD & MBM & Water \\
\hline 1 & $2: 1$ & 360 & 360 & 480 \\
2 & $3: 1$ & 780 & 240 & 480 \\
3 & $4: 1$ & 960 & 240 & 600 \\
4 & $5: 1$ & 1,200 & 240 & 840 \\
5 & $6: 1$ & 720 & 120 & 960 \\
6 & & & 720 \\
\hline
\end{tabular}

a Gainesville house fly diet (GHFD), alfalfa meal $30 \%$, wheat bran $50 \%$, com meal 20\%; meat and bone meal (MBM).

available, and its odor is less offensive. Test diets are shown in Table 1.

Test diets were mixed in bulk and then loosely packed into clear plastic specimen cups $(240 \mathrm{ml}$, $10 \mathrm{~cm}$ high, 4 per diet). Newly hatched $H$. aenescens larvae were added to each cup of diet using the following technique. $H$. aenescens females were allowed to oviposit into $\approx 50 \mathrm{ml}$ of conditioned medium for $12 \mathrm{~h}$. After $24 \mathrm{~h}$ in the growth chamber, newly hatched larvae were ready for use. This technique ensured that the large number of larvae that hatched from the eggs would be concentrated in a relatively small volume of medium. Medium with larvae was placed in a porcelain tray ( 41 by 25 by $6 \mathrm{~cm}$ high). Larvae were picked from the medium and transferred to the surface of the test diets ( 25 per cup) with a natural-bristle artist's brush (No. 4) moistened with water.

Cups were covered with muslin cloth secured with rubber bands and placed in the growth chamber. Development time to the pupal stage was recorded. Pupae were weighed and held for eclosion of adults.

Mass Production. Test diet $(\approx 6,000 \mathrm{ml})$ selected for mass production of $H$. aenescens was measured into larval rearing trays ( 50 by 40 by 10 $\mathrm{cm}$ ) (Morgan 1986) and moistened with water at a ratio of $1: 1$ by volume. To determine the optimum number of pupae that could be produced in this volume of diet, trays were seeded with either $1(\approx 10,000), 2(\approx 20,000)$, or $3 \mathrm{ml}(\approx 30,000)$ of H. aenescens eggs $<24$ h old. Each level of eggs was replicated twice, except for the 1-ml level, which was not replicated. After eggs were added to the test diet, trays were covered with black cloth and put in the growth chamber. Black cloth covers increase the heat and humidity in the trays during the critical period of egg hatch and early larval development. Covers were removed after 3 $\mathrm{d}$ and pupae were separated from diet after $11 \mathrm{~d}$.

Mean pupal weight and percentage of adult eclosion were determined, and total number of pupae and adults was estimated from the total pupal weight and the percentage of adult eclosion, respectively. 
Table 2. Production of $\boldsymbol{H}$. aenescens in plastic cups $(n=4,25$ larvae per cup) with 6 test diets

\begin{tabular}{|c|c|c|c|c|c|c|}
\hline Diet & $\begin{array}{c}\text { CHFD } \\
\text { MBM } \\
\text { ratio }\end{array}$ & $\begin{array}{l}\text { Total } \\
\text { pu- } \\
\text { pae }\end{array}$ & $\begin{array}{l}\text { Mean } \\
\text { pupae } \\
\text { percup } \\
\pm S D\end{array}$ & $\begin{array}{c}\text { Mean } \\
\text { pupal wt } \\
(\mathrm{mg}) \pm \mathrm{SD}\end{array}$ & $\begin{array}{l}\% \\
\text { eclo- } \\
\text { sion }\end{array}$ & $\begin{array}{c}\text { Devel- } \\
\text { opment } \\
\text { time (d) } \\
\pm \mathrm{SD}^{a}\end{array}$ \\
\hline 1 & $1: 1$ & 83 & $20.8 \pm 1.48$ & $16.5 \pm 0.23$ & 72.4 & $10.1 \pm 2.22$ \\
\hline 2 & $2: 1$ & 82 & $20.5 \pm 0.50$ & $16.2 \pm 0.33$ & 65.8 & $10.1 \pm 2.36$ \\
\hline 3 & $3: 1$ & 76 & $19.0 \pm 2.92$ & $16.9 \pm 0.42$ & 79.6 & $9.1 \pm 2.02$ \\
\hline 4 & $4: 1$ & 86 & $21.5 \pm 3.20$ & $17.1 \pm 0.21$ & 58.5 & $11.3 \pm 3.02$ \\
\hline 5 & $5: 1$ & 89 & $22.3 \pm 1.25$ & $16.9 \pm 0.24$ & 90.1 & $8.6 \pm 1.50$ \\
\hline 6 & $6: 1$ & 97 & $24.3 \pm 2.77$ & $16.8 \pm 0.19$ & 91.5 & $8.5 \pm 1.32$ \\
\hline
\end{tabular}

Giainesville house Hy diet (GHFD), alfalfa meal 30\%, wheat bran $50 \%$, com meal $20 \%$; meat and bone meal (MBM).

${ }^{a}$ From lst instar to pupa.

\section{Results and Discussion}

Egg Collection. Quantification was not necessary to determine that the covered oviposition device (Fig. 1) was preferred by $H$. aenescens. Flies filled the interior of the device and readily oviposited in the creases on the underside of the clothwrapped ball of conditioned medium. In contrast, few flies were attracted to the house fly egg collection device. Enough eggs to set a 30,000-egg tray can be collected in $<24 \mathrm{~h}$ with the covered oviposition device ( 2 cages with $\approx 6,000$ adults per cage; 1 device per cage); to collect a similar number of eggs with the house fly egg collection device would require several days.

Diet Selection. Diets 5 and 6 were considered in the final selection of a standard diet for rearing $H$. aenescens because of their desirable performance in all parameters measured (Table 2). Pupae produced by all diets were similar in weight, but diets 5 and 6 produced the most pupae per cup. Mean development time was shortest for diets 3,5 , and 6 , but percentage of eclosion was best for pupae produced by diets 5 and 6 . Although diets 5 and 6 produced similar results, diet 5 was chosen as the Gainesville $H$. aenescens diet because it allowed for greater variability in measuring and mixing error.

Mass Production. When $1 \mathrm{ml}$ of eggs $(\approx 10,000)$ was added to the Gainesville $H$. aenescens diet in a colony rearing tray, pupal and adult yields were only 20.3 and $18.9 \%$, respectively (Table 3 ). The greatest percentage of pupal and adult yields were produced when $2 \mathrm{ml}$ of eggs $(\approx 20,000)$ were used, but the greatest numerical pupal and adult yields were produced when $3 \mathrm{ml}$ of eggs $(\approx 30,000)$ were used. Because the covered oviposition device allows collection of superfluous numbers of eggs in $24 \mathrm{~h}$, and because we need as many adults as possible for field releases, we add $3 \mathrm{ml}$ of $H$. aenescens eggs to larval rearing trays containing Gainesville H. aenescens diet (test diet 5).

The covered oviposition device is now routinely used for collection of eggs in our $H$. aenescens colony. Johnson and Venard (1957) recovered egg masses from within an oviposition medium and estimated the number (between 300 and 400) placed in a measured amount of larval medium. Other authors who described rearing procedures estimated the numbers of eggs being placed directly into larval rearing medium by adult flies (HIogsette 1979, Turner and Carter 1990). With the covered oviposition device (and the house fly egg collection device), Hies oviposit on the cloth surrounding the ball of conditioned medium. Eggs can easily be washed off the cloth into collection containers and measured in centrifuge tubes (Bailey et al. 1975).

The 24-h egg collection period for $H$. aenescens is longer than the one required for our colonized house flies (3-4 h) (Hogsette 1992). However, a longer period should be expected because the average egg mass consists of 120-150 eggs for house flies (James 1947), but only 74 eggs for $H$. aenescens (Johnson and Venard 1957). Besides having smaller egg masses, $H$. aenescens females do not oviposit as quickly as house fly females.

We attribute the attractiveness of the covered oviposition device to the behavior of $H$. aenescens. In the field, $H$. aenescens adults appear to prefer dark places, such as the manure pits in poultry houses (Nolan and Kissam 1987). The inside of the covered oviposition device is dark in relation to other areas in the colony cages. In the colony, we routinely observe $H$. aenescens adults clustering in tight masses in the cage corners and at the interface between the cage floor and objects inside the cage, such as the 2-liter water container. We observe what appears to be the same clustering behavior inside the covered oviposition devices, but this behavior was never observed when house fly egg collection devices were placed in cages with H. aenescens.

When devising a diet for mass-rearing $H$. aenescens, we knew from past experience that the

Table 3. Mass production of $H$. aenescens with test diet 5 and 3 levels of eggs per tray

\begin{tabular}{lcccccr}
\hline \hline $\begin{array}{c}\text { Eggs per } \\
\text { tray }(n)\end{array}$ & $\begin{array}{c}\text { Total pupal } \\
\text { wt, g }\end{array}$ & $\begin{array}{c}\text { Mean pupal wt } \\
\pm \mathrm{SD}(n), \mathrm{mg}\end{array}$ & $\begin{array}{c}\text { Est. total } \\
\text { pupae }\end{array}$ & $\begin{array}{c}\text { \% yield } \\
\text { (pupae) }\end{array}$ & $\begin{array}{c}\text { \% enclosure } \\
(n)\end{array}$ & $\begin{array}{c}\text { Total adults } \\
\text { \% yield } \\
\text { adults }\end{array}$ \\
\hline $10,000(1)$ & 33.3 & $16.4 \pm 0.89(10)$ & 2,033 & 20.3 & $93.0(200)$ & 1,890 \\
$20,000(2)$ & 171.9 & $16.4 \pm 0.50(20)$ & 20,962 & 52.4 & $94.0(200)$ & 18.9 \\
$30,000(2)$ & 207.3 & $16.6 \pm 0.64(20)$ & 24,926 & 41.5 & $98.0(200)$ & 24,427 \\
\hline
\end{tabular}

Test diet 5, Gainesville house fly diet (alfalfa meal $30 \%$, wheat bran $50 \%$, corn meal $20 \%$ ) $83.3 \%$, meat and bone meal $16.7 \%$.

a percentige of yield (pupae) $=$ (total pupae $\div$ total eggs) $\times 100$.

$b$ Percentage of yield $($ adults $)=($ total adults $\div$ total eggs $) \times 100$. 
Gainesville house fly diet would have to be fortified with a protein source. Without a protein source, survival in a grain-base diet can be as low as $4 \%$ (Hogsette 1979). However, too much of the protein source causes a reduction in diet friability and diet components tend to clump and settle tightly in the rearing trays. We attribute the decreases in survival and increases in development time associated with test diets $1-4$ to superfluous amounts of meat and bone meal in those diets (Table 2). As might be expected, pupal weight was not adversely affected by increased protein levels. We have observed $H$. aenescens larvae in substrates of compacted poultry feed in the field, but for laboratory purposes, a more porous diet produces a higher yield of flies in a shorter time with no reduction in size.

Results from diets 5 and 6 are quite similar ( Table 2), and it appeared at first that diet 6 would be the diet of choice. However, after a number of rearing trials using both diets, diet 5 produced the most consistent results with mass-rearing techniques and the inherent variability in measurement and mixing of constituents.

When $H$. aenescens is mass-reared in large trays, there is a fairly large amount of larval mortality for reasons that we cannot fully explain (Table 3). Similar unexplained levels of larval mortality have been observed with $H$. aenescens (Hogsette 1979) and other flies, notably the stable fly (Bridges and Spates 1983, Hogsette 1992). Although our laboratory mortality rate seems to be high, we do not know how different it is from natural field mortality. Cannibalism might be suspected, but $H$. aenescens larvae are not cannibalistic (Hogsette 1979).

Hydrotaea aenescens larvae could be adversely affected by the tremendous amount of heat $\left(42^{\circ} \mathrm{C}\right)$ they produce in the larval medium (Hogsette 1979). Trays of medium with developing larvae must be elevated so heat can dissipate through the bottom of the trays. Heat build-up will cause larvae to vacate trays placed on flat surfaces. However, if heat alone is causing increased larval mortality, we question why larvae remain in the trays instead of secking more suitable temperatures.

Gainesville house fly diet is ordered in 0.91-t lots and costs $\approx \$ 7.50$ per $23-\mathrm{kg}$ bag (40 bags per lot) (Hogsette 1992). Meat and bone meal is purchased separately ( $\approx \$ 18.00$ per $23-\mathrm{kg}$ bag) and mixed by volume with Gainesville house fly diet $(5$ parts Gainesville house fly diet: 1 part meat and bone meal) at the laboratory. The amounts of Gainesville house fly diet and meat and bone meal required to mix 1 larval rearing tray of Gainesville $H$. aenescens diet are $4,500 \mathrm{ml}(\approx 2 \mathrm{~kg})$ and $1,500 \mathrm{ml}(\approx 1$ $\mathrm{kg})$, respectively. The cost per rearing tray $(12,200$ adults) is $\$ 0.65$ (Gainesville house fly diet: $\$ 7.50$ $\div[23 \mathrm{~kg} \div 2 \mathrm{~kg}]$ ) plus $\$ 0.78$ (meat and bone meal: $\$ 18.00 \div[23 \mathrm{~kg} \div 1 \mathrm{~kg}])$, or $\$ 1.43$ per tray and $\approx \$ 0.12$ per 1,000 adults. Tumer et al. (1992), who reared $H$. aenescens in smaller quantities than we did, estimated their cost to be $\$ 0.18$ per 1,000 adults.

\section{Acknowledgments}

We thank G. Langley (USIDA-ARS, Gainesville, FL) for her technical assistance and J. Medley (Department of Entomology and Nematology, Institute of Food and Agricultural Sciences, University of Florida) for preparation of the figure.

\section{References Cited}

Adums, R. G. 1984. Ophyra species as predators in animal houses, with a key to species occurring in Europe (Diptera: Muscidae). Entomol. Gaz. 35: 243246.

Bailey, D. L., T. L. Whitfield, and G. C. LaBrecque. 1975. Laboratory biology and techniques for mass producing the stable fly, Stomoxys calcitrans (L.) (Diptera: Muscidae). J. Med. Entomol. 12: 189-193.

Betke, P., R. Ribbeck, and R. Schmäschke. 1991. Biological control of house flies with the antagonist Ophyra aenescens in animal production units, pp. 504-515. Proceedings, 7th International Congress on Animal Hygiene. Leipzig, 20-24 August, 1991 (in German).

Bridges, A. C., and G. E. Spates. 1983. Larval medium for the stable Aly, Stomoxys calcitrans (L.) Southwest. Entomol. 8: 6-10.

Farkas, R., and T. Jantnyik. 1990. Laboratory studies on Hydrotaea aenescens as a predator of house Hy larvae (Diptera: Muscidae). Parasitol. Hung. 23: 103108.

Farkas, R., and L. Papp. 1990. Hydrotaea (Ophyra) species as potential biocontrol agents against Musca domestica (Diptera) in Hungary, pp. 169-176. In $\mathrm{D}$. A. Rutz and R. S. Patterson [eds.], Biocontrol of arthropods affecting livestock and poultry. Westview, Boulder, $\mathrm{CO}$

Geden, C. J., R. E. Stinner, and R. C. Axtell. 1988. Predation by predators of the house fly in poultry manure: effects of predator density, feeding history, interspecific interference, and field conditions. Environ. Entomol. 17: 320-329.

Hogsette, J. A. 1979. The evaluation of poultry pest management techniques in Florida poultry houses. Ph.D. dissertation, University of Florida, Gainesville. 1992. New diets for production of house flies and stable flies (Diptera: Muscidae) in the laboratory. I. Econ. Entomol. 85: 2291-2294.

Hogsette, J. A., and P. G. Koehler. 1992. Comparative toxicity of aqueous solutions of boric acid and polybor 3 to house flies (Diptera: Muscidac). J. Econ. Entomol. 85: 1209-1212.

James, M. T. 1947. The flies that cause myiasis in man. U.S. Dep. Agric. Misc. Publ. 631.

Johnson, W. T., and C. E. Venurd. 1957. Observations on the biology and morphology of Ophyra aenescens (Diptera: Muscidae). Ohio J. Sci. 57: 21-26.

Morgan, P. B. 1986. Mass culturing microhymenopteran pupal parasites (Hymenoptera: Pteromalidae) of filth breeding flies, pp. 77-87. In R. S. Patterson and D. A. Rutz [eds.], Biological control of muscoid flies. Misc. Publ. Entomol. Soc. Am. 61.

Morrison, F. B. 1961. Feeds and feeding, abridged. Morrison, Clinton, IA. 
Müller, P. 1982. On the significance of the Musca domestica-antagonist Ophyra aenescens (Diptera: Muscidae): III. Laboratory investigation into the interaction between the larvae of $M$. domestica and $O$, aenescens. Angew. Parasitol. 23: 143-154 (in German).

Nolan, M. P., III, and J. B. Kissam. 1985. Ophyra aenescens: A potential bio-control alternative for house fly control in poultry houses. J. Agric. Entomol. 2: 192-195.

1987. Nuisance potential of a dump fly, Ophyra aenescens (Diptera: Muscidae), breeding at poultry farms. Environ. Entomol. 16: 828-831.

Ribbeck, P., P. Betke, P. Müller, H. Schumann, and Th. Heipe. 1987. Detrimental effects and control in intensive animal production. Monh. Vet. Med. 42: 517-521 (in German).

Roddy, L. R. 1955. A morphological study of the respiratory homs associated with the puparia of some
Diptera, especially Ophyra aenescens (Wied.). Ann. Entomol. Soc. Am. 48: 407-415.

Sick, F. 1971. Ophyra aenescens (Wied.) (IDiptera: Muscidae) new for North Germany. Faun. okol. Mitt. 4: 21-22.

Turner, E. C., Jr., and L. Carter. 1990. Mass rearing and introduction of Ophyra aene'scens (Wiedemanm) (Diptera: Muscidae) in high-rise caged layer houses to reduce house fly populations. J. Agric. Entomol. 7: 247-257.

Turner, E. C., Jr., P. L. Ruszler, P. Dillon, L. Carter, and R. Youngman. 1992. An integrated pest management program to control house flies in commercial high rise houses. J. Appl. Poultry Re's. 1: 242-250.

Received for publication 9 November 199.4; accopted 24 April 1995 